\title{
Expression of an Antifungal Peptide in Saccharomyces: A New Approach for Biological Control of the Postharvest Disease Caused by Colletotrichum coccodes
}

\author{
Richard W. Jones and Dov Prusky
}

\begin{abstract}
First author: Vegetable Laboratory, Henry A. Wallace Beltsville Agricultural Center, Agricultural Research Service, U.S. Department of Agriculture, Beltsville, MD 20705; and second author: Department of Postharvest Science of Fresh Produce, Institute for Technology and Storage of Agricultural Products, The Volcani Center, Agricultural Research Organization, Bet Dagan 50250, Israel. Accepted for publication 14 August 2001.
\end{abstract}

\begin{abstract}
Jones, R. W., and Prusky, D. 2002. Expression of an antifungal peptide in Saccharomyces: A new approach for biological control of the postharvest disease caused by Colletotrichum coccodes. Phytopathology 92:33-37.

A cecropin A-based peptide inhibited germination of Colletotrichum

quence for secretion of the peptide, and expressed in yeast. Yeast transformants inhibited the growth of germinated $C$. coccodes spores and inhibited decay development caused by $C$. coccodes in tomato fruits. Expression of the antifungal peptide in yeast therefore represents a new approach for the biological control of postharvest diseases.
\end{abstract} coccodes at $50 \mu \mathrm{M}$. The DNA sequence encoding the peptide was cloned in pRS413, using the Saccharomyces cerevisiae invertase leader se-
Additional keywords: antifungal peptides, biocontrol mechanism.
Losses from postharvest pathogens on fruits and vegetables have been principally managed by the use of synthetic fungicides (10). Consumer concerns about possible risks associated with the use of fungicides, along with development of pathogen resistance to certain fungicides, have resulted in an intensive search for safer, more effective control options that pose minimal risk to human health and the environment. Significant progress has been made in developing potential biological alternatives to synthetic fungicides for the control of postharvest diseases of fruits and vegetables (27). The use of microorganisms, particularly yeasts occurring naturally on the surface of fruits or vegetables, usually has been preferred for the control of postharvest disease $(6,8,15,16,18,25)$. Yeasts are suitable as biocontrol agents of postharvest diseases because they (i) rapidly colonize and survive on fruit surfaces for long periods of time under different conditions; (ii) use available nutrients to proliferate rapidly, limiting nutrient availability to the pathogen; and (iii) are generally unaffected by fungicides used commercially.

Several yeast antagonists have been reported to effectively inhibit the development of postharvest pathogens on various fruits $(6-8,23)$. Among these yeasts, Pichia guilliermondii Wicherham and Candida oleophila Montrocher were developed into commercial products $(9,14)$. However, one of the major problems with the use of those products is their insufficient and inconsistent performance under commercial conditions. Consequently, they are used in combination with low concentrations of postharvest fungicides (9) or by using preharvest treatments with an antagonist (1). Another significant problem is that the reported antagonists are mainly used to control wound pathogens but not for pathogens invading directly through the cuticle and causing quiescent infection (28).

Corresponding author: D. Prusky; E-mail address: prusky33@netvision.net.il

Publication no. P-2001-1116-01R

This article is in the public domain and not copyrightable. It may be freely reprinted with customary crediting of the source. The American Phytopathological Society, 2002.
The current study was undertaken to investigate the possibility of expressing a DNA sequence in yeast to allow for the production of an antifungal peptide to produce an improved biocontrol organism (12). Small antibacterial peptides with lytic activity have been found in a broad variety of species (3). Two main structural patterns were identified: one characterized by a $\beta$-sheet structure with two or three intramolecular disulfide bonds, and a second group possessing an $\alpha$-helical motif typical of cecropin families (2) that were used in the present work. Most of the work on the antimicrobial properties of cecropin $\mathrm{A}$ and $\mathrm{B}$ peptides has concentrated on their activities against plant-pathogenic bacteria. Consequently, these peptides have been studied with a view to engineering bacterial disease resistance in plants. However, antifungal activity was also reported for these peptides $(5,21)$. In an effort to improve the control of postharvest decay by biological means, we have developed a new approach to control postharvest pathogens by expressing a lytic peptide in Saccharomyces cerevisiae Hansen. We chose the tomato fruit fungal pathogen Colletotrichum coccodes (Wallr.) S. J. Hughes as a target to demonstrate the potential of bioengineered yeast in disease control.

\section{MATERIALS AND METHODS}

Tomato fruit, fungal isolates, and growth media. Tomato fruit (Lycopersicum esculentum cv. Roma) were obtained from a local grocery store. A single-spore isolate of $C$. coccodes was obtained from a decayed tomato (cv. Roma). Three-week-old conidia were harvested from Mathur's medium $\left(\mathrm{M}_{3} \mathrm{~S}\right)$ plates (26) and used for culture and fruit inoculation. Spore production was estimated on 3-week-old colonies on $\mathrm{M}_{3} \mathrm{~S}$ plates at $20^{\circ} \mathrm{C}$ by counting spores with a haemacytometer (Brand, Wertheim, Germany).

Antifungal activity of the synthesized peptide. The antifungal peptide represents an internal portion of cecropin A. The peptide (WKLFKKILKVL) was synthesized by Genosys (Genosys, The Woodlands, TX). Antifungal activity against $C$. coccodes was tested in water solutions at $0.5 \mu \mathrm{M}$ and up to $5 \mathrm{mM}$ of the pure peptide. Peptide stock solutions were prepared at twofold concentrations of the final concentrations tested and mixed at a 1:1 ratio 
(5 $\mu$ l of each solution) with a $C$. coccodes suspension of $2.5 \times$ $10^{5}$ spores per $\mathrm{ml}$. Spore germination was carried out on a glass slide at $25^{\circ} \mathrm{C}$ and high humidity over $12 \mathrm{~h}$. Germinated spores were those where the germ tube was twice the length of the spore.

Fruit protection assays were carried out in the presence of the synthesized peptide. Fruit were inoculated by wounding to a depth of 2 to $3 \mathrm{~mm}$ and placing $10 \mu \mathrm{l}$ of $C$. coccodes spore suspension $\left(10^{6}\right.$ spores per $\left.\mathrm{ml}\right)$ at two points, one on each side of the longitudinal axis of 15 fruit. The fruit then were incubated at $20^{\circ} \mathrm{C}$ in $90 \%$ relative humidity for 6 days.

Construction of invertase-antimicrobial peptide fusion, yeast transformation, and isolate selection. The invertase signal sequence from $S$. cerevisiae Hansen (4) was cloned by two rounds of polymerase chain reaction (PCR). In the first round, a 626-bp fragment was obtained using primers IF1 (5'-GGGTTTTTCCATGGAG-3') and IR1 (5'-GAAGTAGCATGGCCCC-3'). The

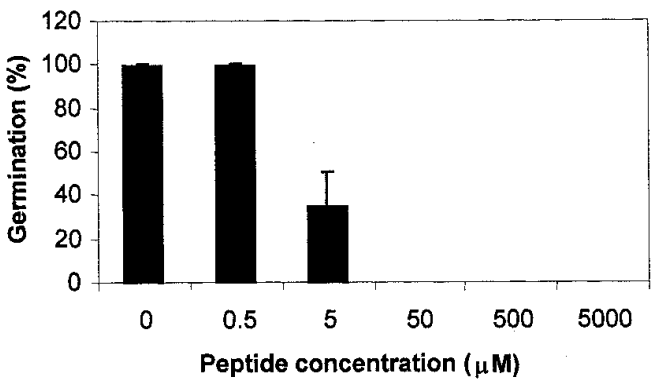

Fig. 1. In vitro antifungal activities of synthetic antifungal cecropin A-based peptide on Colletotrichum coccodes germination. Fungal germination is expressed as a percentage of the germination in control spores (100\% germination in water without the peptide is $\approx 87 \%$ ). Three or more replicates of each bioassay were performed, each time with a different spore suspension. fragment was gel purified (Zymo Research, Orange, CA ) and used for the second round of amplification with primers IF2 (5'CATACTCTAGAGAAACAAGC-3') and IR2 (5'P-CGTTTGTCATTGATTGGC-3'). The second round yielded a 124-bp fragment that was gel purified and used for ligation to the antimicrobial peptide sequence.

The antimicrobial peptide fragment was amplified from a prior construct (19) by using primers PEPF (5'P-TGGAACTCTTTAAG-3') and PEPR (5'-CTCGAGCTACTAGAGCACTTTGAGAATCTTCTTAAAGAGTTTCC-3'). The prior construct was developed through sequential PCR to provide the complete antimicrobial sequence for an internal 11-amino-acid sequence of cercropin A, modified for protease resistance (5). Each of the prior PCR reactions used Thermopol polymerase (New England Biolabs, MA) and the cycling parameters of $94^{\circ} \mathrm{C}$ for $5 \mathrm{~min}$ followed by 30 cycles of $94^{\circ} \mathrm{C}$ for $1 \mathrm{~min}, 53^{\circ} \mathrm{C}$ for $1 \mathrm{~min}, 72^{\circ} \mathrm{C}$ for $1 \mathrm{~min}$, and a final cycle of $72^{\circ} \mathrm{C}$ for $10 \mathrm{~min}$. The PCR product was gel purified and used in a ligation reaction with the invertase signal sequence (Fast-Link, Epicentre, Madison, WI). One-tenth of the reaction volume was used to amplify the ligated product using primers IF2 and PEPR, ExTaq polymerase (Fisher Scientific, Chicago) and the previously described cycle parameters. The PCR product was cloned using pCR2.1-TOPO (Invitrogen, Carlsbad, CA).

The invertase signal:antimicrobial peptide insert was released from subsequent plasmid preparations by double digestion with $X h o I$ and $X b a I$, sites contained within primers PEPR and IF2, respectively. The end-digested fragment was gel purified before use in ligation. The shuttle vector pRS413 (Stratagene, La Jolla, CA) was digested with the same restriction enzymes and gel purified. The insert and pRS413 were ligated (Fast-Link ligase) and used for bacterial transformation. Insert-containing colonies were identified by PCR screening and the plasmid propagated. The shuttle vector pRS413 contains the autonomous replication sequence (ARS) and centromeric sequence (CEN6) which allows
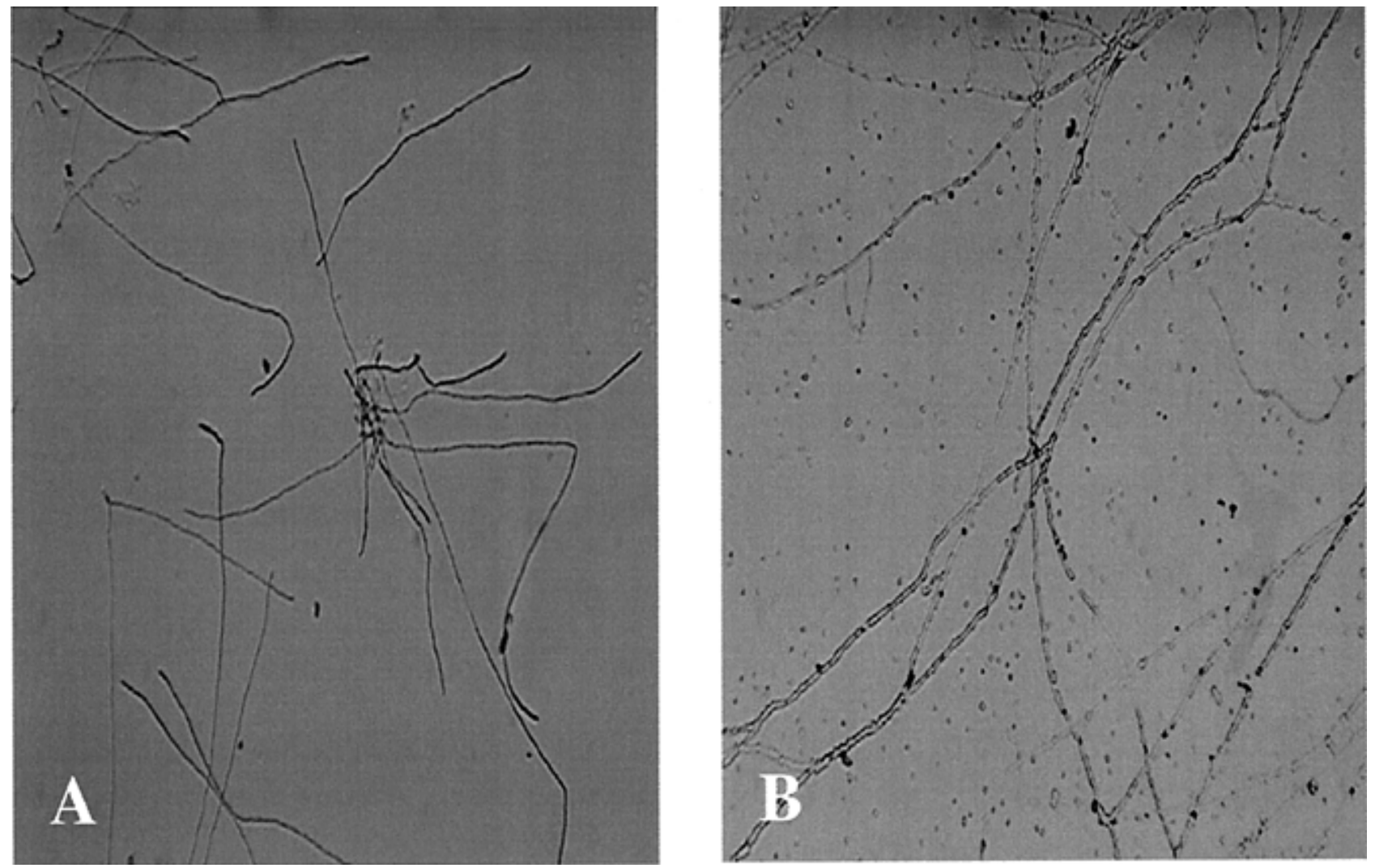

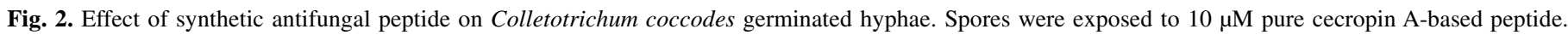

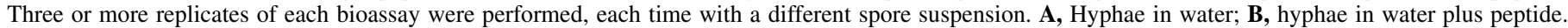
Notice the loss of hyphal integrity in the presence of the peptide. Observations were done with a phase contrast light microscope (BH-2 Olympus). 
for high copy replication in a nonintegrative manner. The purified plasmid containing the invertase signal:antimicrobial peptide sequence and the plasmid alone were used for transformation of YPH500 yeast cells (Stratagene) using the lithium acetate-polyethylene glycol-mediated transformation at $30^{\circ} \mathrm{C}(11)$ and selected on synthetic dextrose (SD) minimal media with amino acids, lacking histidine, at the same temperature. Histidine-complemented colonies were collected 8 days later and transferred to new yeast peptone adenine dextrose (YPAD) (Difco Laboratories, Detroit) agar plates. Colonies were transferred back to L-histidine-lacking media to test complementation stability and then back to YPAD agar.

Selection of biologically active $S$. cerevisiae transformants and fruit protection assays. Histidine-complemented colonies were grown in $1 \mathrm{ml}$ of YPAD broth for $24 \mathrm{~h}$ at $30^{\circ} \mathrm{C}$ and $25 \mu \mathrm{l}$ of the yeast suspension was combined with $5 \mu$ of $C$. coccodes spores $\left(1.2 \times 10^{6}\right.$ spores per $\left.\mathrm{ml}\right)$. Treated spores in the presence of the yeast cells were germinated as described before. For fruit protections assays, the suspension containing the growing yeast cells and the Colletotrichum spores was incubated at room temperature for $12 \mathrm{~h}$ and then transferred to freshly wounded tomato fruit. Control inoculations included spores of the wild type $C$. coccodes in a mixture with $25 \mu \mathrm{l}$ of the YPAD media inoculated $24 \mathrm{~h}$ earlier with either untransformed $S$. cerevisiae (WT) or $S$. cerevisiae containing the vector pRS413 only (YWT). Fruit were incubated for 6 days as described before. All experiments were repeated at least three times.

Fast protein liquid chromatography analysis of yeast extracts. Fast protein liquid chromatography (FPLC) was carried out with a Liquid Chromatography Controller LCC-500 Plus (Pharmacia Biotech, AB, Uppsala, Sweden) using two Superose12 filtration columns (NR1013) connected in series (Pharmacia Biotech). The columns were equilibrated with $50 \mathrm{mM}$ phosphate, $150 \mathrm{mM} \mathrm{NaCl}$ (PBS), $\mathrm{pH} 7.0$, that was filtered though a $0.45-\mu \mathrm{m}$ Millipore membrane (Millipore Corp., Bedford, MA) prior to use.

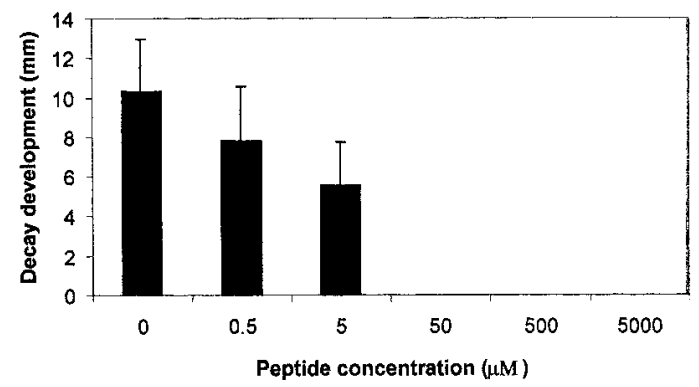

Fig. 3. In vivo antifungal activities of synthetic antifungal cecropin A-based peptide on the inhibition of anthracnose caused by Colletotrichum coccodes. Decay development is determined as diameter of decay compared to the untreated spores. Three replicates of each inoculation were performed, each time with a different spore suspension.

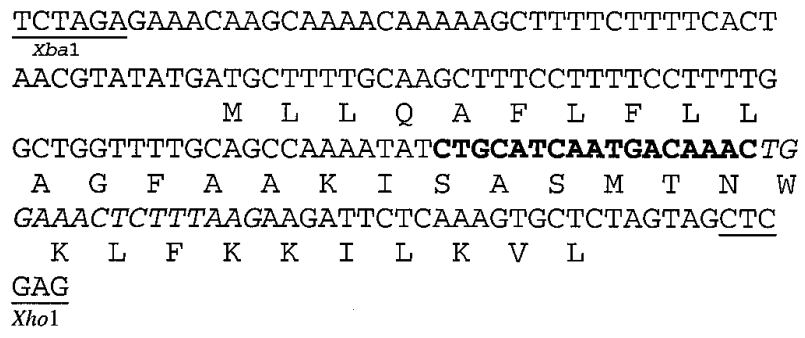

Fig. 4. Construction of invertase leader sequence and antimicrobial peptide sequence. Two primers IR2 (in bold) and PEPF (in italics) were phosphorylated to allow for ligation in the proper reading frame. Terminal primers contained the restriction sites needed for ligation into pRS413.
Sample volumes of $50 \mu \mathrm{l}$ were applied to the columns and eluted with PBS at a flow rate of $0.6 \mathrm{ml} / \mathrm{min}$. Peptides were detected by continuous absorbance readings at $280 \mathrm{~nm}$ and chart speed of $2 \mathrm{~mm} / \mathrm{min}$.

To determine the active fraction in FPLC runs, aliquots of $40 \mu \mathrm{l}$ out of 2-ml FPLC fractions were mixed with $5 \mu \mathrm{l}$ of $C$. coccodes spores $\left(1.2 \times 10^{6}\right.$ spores per $\left.\mathrm{ml}\right)$ and incubated as described before.

Plasmid rescue and sequencing. One of the colonies of the transformant Y-20, exhibiting inhibitory activity, was transferred to YPAD broth and cultured overnight. Cells were pelleted, resu-

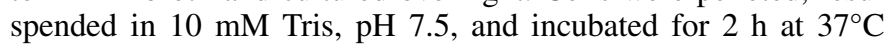
with lyticase at $0.1 \mathrm{mg} / \mathrm{ml}$ (Sigma-Aldrich, St. Louis). Protoplasts were lysed and extracted with phenol/chloroform and the DNA precipitated with $1 / 20 \mathrm{vol}$ of $2 \mathrm{M}$ sodium acetate and $3 \mathrm{vol}$ of ethanol from the supernatant. Precipitated DNA was pelleted after overnight storage at $-20^{\circ} \mathrm{C}$, resuspended in water, and used to transform DH5 $\alpha$ competent cells (Gibco BRL, Gaithersburg, MD). A plasmid from a transformed colony was sequenced to verify the presence of the construct (Center for Agricultural Biotechnology, University of Maryland, College Park).

\section{RESULTS}

Antifungal activity of the synthesized peptide. The synthesized peptide, WKLFKKILKVL, at $50 \mu \mathrm{M}$, inhibited germination of C. coccodes by $100 \%$ (Fig. 1) and showed a $50 \%$ effective dose $\left(\mathrm{ED}_{50}\right)$ of 13.45. At lower concentrations, germination was not inhibited but hyphal growth was reduced. When spores of $C$.
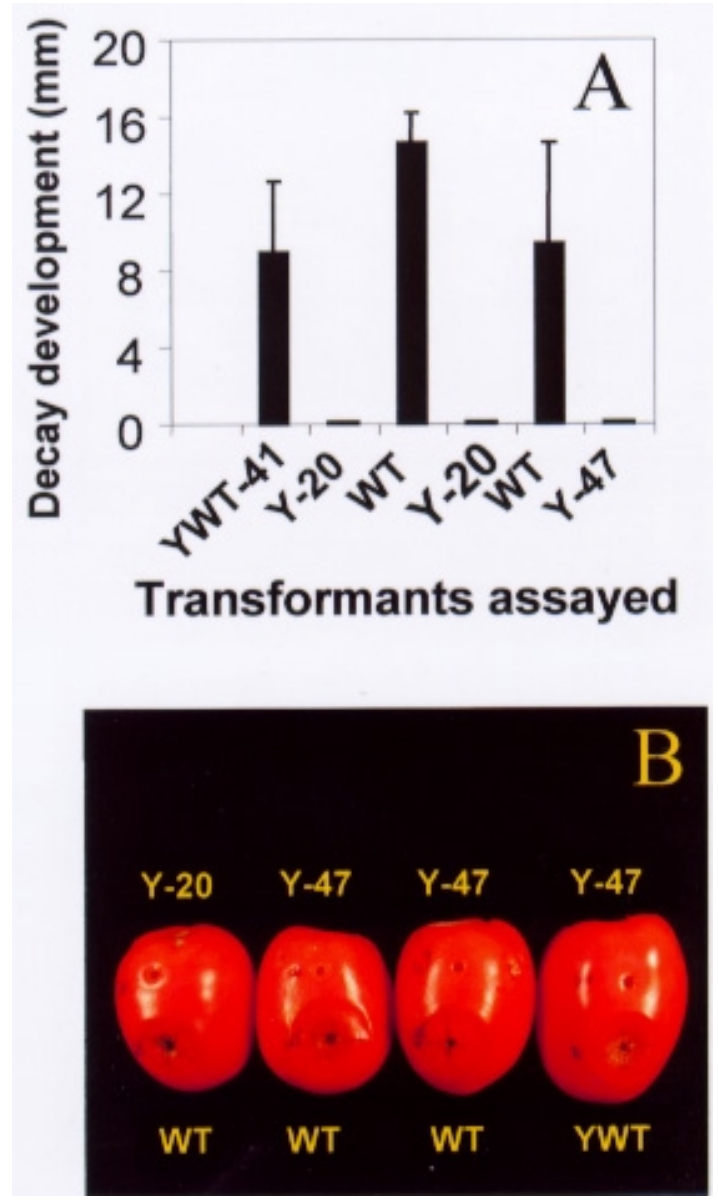

Fig. 5. Decay development caused by Colletotrichum coccodes in tomato fruit coinoculated in the presence of transformed yeast isolates expressing the peptide. A, Decay development measurements; B, symptom development of anthracnose. Isolates Y-20 and Y47 are transformed yeast expressing the antifungal peptide. Isolate YWT is a transformed yeast containing only the vector pRS413 and WT is the wild-type yeast strain. 
coccodes were germinated at $5 \mu \mathrm{M}$, a percentage could germinate but the mycelium subsequently lysed and no further growth was observed (Fig. 2).

Decay development in tomato fruit following direct inoculation with $C$. coccodes incubated in the presence of the synthesized peptide was completely inhibited at $50 \mu \mathrm{mol}$ and partially inhibited at 5 and $0.5 \mu \mathrm{mol}$ (Fig. 3).

Construction of invertase-antimicrobial peptide fusion. We relied on phosphorylated primers to ligate the invertase signal sequence to the antimicrobial peptide sequence in the proper reading frame (Fig. 4). Use of one terminal primer from each fragment for selection of the ligated product avoided the need for additional cloning steps. Colonies containing the insert were identified at each step by PCR screening. Two final yeast transformants, Y-20 and Y-47, were further analyzed for their capability to secrete the peptide and inhibit $C$. coccodes.

FPLC analysis of yeast peptide production. FPLC runs of the YPAD extracts of Y-20, Y-47 containing the sequences encoding for the invertase signal:antimicrobial peptide, and YWT-41 containing only the plasmid were compared to the synthesized peptide dissolved in water. A peak was observed at a retention time of $59 \mathrm{~min}$ in the synthesized peptide sample and in samples from Y20 and Y-47, but not in the YWT-41 sample. This peak contained the biological activity and inhibited germination of $C$. coccodes by $\approx 70 \%$ (data not shown).

Germination assays and fruit protection assays of transformed isolates. Germination of $C$. coccodes spores in the presence of YPAD extract of the yeast transformants Y-20 and Y-47 did not inhibit germination but completely prevented growth of hyphae after spore germination. Inoculation of tomato fruit with spores of $C$. coccodes treated for $24 \mathrm{~h}$ with extracts of Y-20 and Y47 resulted in no symptom development after 6 days of incubation at $20^{\circ} \mathrm{C}$, compared with the control transformed yeast YWT- 41 and untransformed WT strains (Fig. 5A and B).

\section{DISCUSSION}

Small peptides related to the host defense system of a variety of organisms have generated increasing agricultural interest based on the prospect of genetically engineering disease resistance in plants $(17,22)$. The activity of antimicrobial peptides has been mainly tested against bacterial pathogens and a few fungal pathogens (5). Thus, these peptides are useful models for expression in transgenic plants to obtain resistance to fungal pathogens. However, the directed expression of such peptides in yeast gives a new perspective on their use for biological control of pathogens and on the direct interaction of the peptide with the target pathogen. At $50 \mu \mathrm{M}$, the synthetic peptide inhibited germination of $C$. coccodes with a significant reduction of inhibition at $5 \mu \mathrm{M}$, suggesting a similar range of effect on the activity reported against Phytophthora infestans and Fusarium spp. (5). We found C. coccodes germination to be more sensitive than $C$. accutatum because, in this species, inhibition of germination was only partially inhibited by $50 \mu \mathrm{M}$ of the synthetic peptide (data not shown). When assessing the impact of antimicrobial peptides on fungal targets, it is important to observe the fungus throughout the exposure period. While germinating spores formed fungal biomass, it lost viability through disruption of membrane integrity. Thus, although the spores germinated, the hyphae may be unable to initiate an infection. The fact that germinated spores of $C$. coccodes, in the presence of extracts containing the transformed yeast, were unable to cause disease suggests that the peptide is biologically active against germinated spores in fruit tissue. The affected hyphal integrity possibly resulted in the lack of actively growing fungi because no symptom development was observed following inoculation on the fruit. The mechanism of action of the peptide is believed to be interaction of the amphipathic cationic peptide with the phospholipids on the target cell membrane, followed by either channel formation or simple membrane disruption (24). The ability to adopt an amphipathic $\alpha$-helical structure in a membrane environment is thus the major requirement for activity in this type of peptide (13). By incubating the pathogen in the presence of $S$. cerevisiae transformants $\mathrm{Y}-20$ and $\mathrm{Y}-47$, we have been able to completely inhibit fungal growth of $C$. coccodes and the subsequent decay development from germinated spores in tomato fruit. The mechanism of action of this peptide enables a direct interaction between the antifungal peptide and the target pathogen membrane, resulting in a rapid inhibition of the pathogen. This simple mechanism of action is very important in rapidly localizing the germinated spores of the attacking pathogen in the wounded tissue. Biocontrol agents are applied as a postharvest treatment; therefore, the dynamics of secretion of the active peptide should be fast enough to overcome the rapid development of germinated spores at the infection site so that it will fit to the stringent conditions where the biocontrol agent should act. In spite of the fact that the expressed yeast is able to produce biologically active peptides, further work will be needed to confirm the widespread applicability of this method for enhancing biological control.

The transformed yeast has the advantage over transgenic plant strategies in being available for application to a wide range of vegetable and fruit crops. Although some crops are readily transformed, many are not. The yeast is readily transformed and various peptides may be rapidly introduced and expressed. The direct expression of peptides in yeasts could also prevent degradation problems encountered when peptides are expressed in plants. Recent studies indicate that cecropin B peptides are degraded by limited proteolysis and the extent of this degradation varies from one plant species to another (20). The direct interaction of Y-20 and Y-47 with the target pathogen does not preclude the possible effect of proteases from fruit affecting the peptide, but our results suggest that biological control by the peptide is feasible. The peptide we chose is resistant to plant proteases and represents just one of many possible small peptide candidates that could be used for yeast expression. The engineering of yeast expressing an antifungal peptide is a new approach for the biological control of postharvest pathogens. We envision further improvements and modifications by introducing other peptides, as well as engineering other yeast genera. The lack of activity toward nontarget organisms by the peptide and the fact that we have used $S$. cerevisiae as a delivery system suggests that this method should provide a safe alternative to other methods for controlling postharvest diseases.

\section{ACKNOWLEDGMENTS}

We thank T. Henderson for technical assistance in FPLC analysis.

\section{LITERATURE CITED}

1. Ben-Arie, R., Droby, S., Zutkhi, J., Cohen, L., Weiss, B., Sarig, P., Zeidman, M., Daus, A., and Chalutz, E. 1991. Preharvest and postharvest biocontrol of Rhizopus rot of table grapes with yeasts. Pages 100-113 in: Biological Control of Postharvest Diseases of Fruits and Vegetables. Proc. Int. Workshop, Shepardstown, WV. USDA-ARS Pub. 92.

2. Boman, H. G. 1995. Peptide antibiotics and their role in innate immunity. Annu. Rev. Immunol. 13:61-92.

3. Boman, H. G., and Hultmark, D. 1987. Cell-free immunity in insects. Annu. Rev. Microbiol. 41:103-126.

4. Carlson, M., Taussig, R., Kustu, S., and Botstein, D. 1983. The secreted form of invertase in Saccharomyces cerevisiae is synthesized from mRNA encoding a signal sequence. Mol. Cell. Biol. 3:439-447.

5. Cavallarin, L., Adreu, D., and San Segundo, B. 1998. Cecropin Aderived peptides are potent inhibitors of fungal plant pathogens. Mol. Plant-Microbe Interact. 11:218-227.

6. Chalutz, E., and Wilson, C. L. 1990. Postharvest biocontrol of green and blue mold and sour rot of citrus fruit by Debaryomyces hansenii. Plant Dis. 74:134-137.

7. Chand-Goyal, T., and Spotts, R. A. 1995. Control of postharvest pear diseases using natural saprophytic yeast colonists and their combination 
with low dosage of thiabendazole. Postharvest Biol. Technol. 7:51-64.

8. Droby, S., Chalutz, E., and Wilson, C. L. 1991. Antagonistic microorganisms as biological control agents of postharvest diseases of fruits and vegetables. Postharvest News Inf. 2:169-173.

9. Droby, S., Cohen, L., Daus, A., Weiss, B., Horev, B., Chalutz, E., Katz, H., Keren-Tzur, M., and Shachnai, A. 1998. Commercial testing of Aspire: A yeast preparation for the biological control of postharvest decay of citrus. Biol. Control 12:97-101.

10. Eckert, J. W., and Ogawa, J. M. 1985. The chemical control of postharvest diseases: Subtropical and tropical fruits. Annu. Rev. Phytopathol. 23:421-454.

11. Elble, R. 1992. A simple and efficient procedure for transformation of yeast. BioTechniques 13:18-20.

12. Florack, D., Allefs, S., Bollen, R., Bosch, D., Visser, B., and Stiekema, W. 1995. Expression of giant silkmoth cecropin B genes in tobacco. Transgenic Res. 4:132-141.

13. Hancock, R. E. W., Falla, T., and Brown, M. 1995. Cationic bactericidal peptides. Adv. Microbiol. Physiol. 37:135-175.

14. Hofstein, R., Fridlender, B., Chalutz, E., and Droby, S. 1994. Large scale production and pilot testing of biocontrol agents of postharvest diseases. Pages 89-100 in: Biological Control of Postharvest Diseases of Fruits and Vegetables-Theory and Practice. C. L. Wilson and M. E. Wisniewski, eds. CRC Press, Boca Raton, FL.

15. Janisiewicz, W. J. 1991. Biological control of postharvest diseases. Pages 301-326 in: Handbook of Applied Mycology: Soils and Plants. Vol. 1. D. K. Arora, B. Rai, K. G. Mukerji, and K. L. Knudsen, eds. Dekker, New York.

16. Janisiewicz, W. J., Peterson, D. L., and Bors, R. 1994. Control of storage decay of apples with Sporobolomyces roseus. Plant Dis. 78:466-470.

17. Jaynes, J. M., Nagpala, P., Destéfano-Beltrán, L., Huang, J. H., Kim, J., Denny, T., and Cetiner, S. 1993. Expression of a cecropin B lytic peptide analog in transgenic tobacco confers enhanced resistance to bacterial wilt caused by Pseudomonas solanacearum. Plant Sci. 89:43-53.

18. Jeffries, P., and Jeger, M. J. 1990. The biological control of postharvest diseases of fruit. Postharvest News Inf. 1:365-368.

19. Jones, R. W. 2000. Analysis of prosystemin in potato. (Abstr.) Am. J. Potato Res. 77:404.

20. Owens, L. D., and Heutte, T. M. 1997. A single amino acid substitution in the antimicrobial defense protein cecropin B is associated with diminished degradation by leaf intercellular fluid. Mol. Plant-Microbe Interact. 10:525-528.

21. Powell, W. A., Catranis, C. M., and Maynard, C. A. 1995. Synthetic antimicrobial peptide design. Mol. Plant-Microbe Interact. 8:792-794.

22. Rao, A. G. 1995. Antimicrobial peptides. Mol. Plant-Microbe Interact. 8:6-13.

23. Roberts, R. G. 1990. Biological control of mucor rot of pear by Cryptococcus laurentii, C. flavus, and C. albidus. (Abstr.) Phytopathology 80:1051.

24. Shai, Y. 1995. Molecular recognition between membrane spanning polypeptides. Trends Biochem. Sci. 20:460-464.

25. Smilanick, J. L., Denis-Arrue, R., Bosch, J. R., Gonzales, A. R., Henson, D. J., and Janisiewicz, W. J. 1993. Biocontrol of postharvest brown rot of nectarines and peaches by Pseudomonas species. Crop Prot. 2:513-520.

26. Tu, J. C. 1985. An improved Mathur's medium for growth, sporulation and germination of spores of Colletotrichum lindemuthianum. Microbiosis 44:87-93.

27. Wilson, C. L., and Wisniewski, M. E. 1994. Biological Control of Postharvest Diseases of Fruits and Vegetables-Theory and Practice. CRC Press, Boca Raton, FL.

28. Yakoby, N., Zhou, R., Kobiler, I., Dinoor, A., and Prusky, D. 2001. Development of Colletotrichum gloeosporioides REMI mutants as biocontrol agents against anthracnose disease in avocado fruits. Phytopathology 91:143-148. 